\title{
A CLINICAL EPIDEMIOLOGIC STUDY IN A SCHISTOSOMIASIS MANSONI ENDEMIC AREA
}

\author{
(Tuparecê, Minas Geraîs) (1)
}

Mark D. G. GumMaraes (2), Hélio L. de BarRos (3) and Naftale KATZ (4)

\section{S U M M A R Y}

A population-based clinical epidemiologic study on schistosomiasis mansoni was carried out in Tuparecê, Minas Gerais. The patients were interviewed for symptoms, water contact, past history and examined for spleen and liver enlargement. From the 830 people registered in the census, $777(93.6 \%)$ had their stools examined (Kato-Katz method) and $696(83.9 \%)$ were clinically evaluated. The overall index of Schistosoma mansoni infection was $43.2 \%$. Significant and increased infection risks could be detected in the young age group (2-14 years old) regarding occupation, time of residence in the area and frequency of water contact. Bloody stools were significantly more prevalent among positives, while diarrhea was significantly more prevalent among those negative. The area was shown to have a low morbidity as well as a low intensity of infection measured by the number of $\mathbf{S}$. mansoni eggs per gram of feces. A close correlation was found between water contact pattern and the age prevalence curve. It has emphasized the importance of habits in determining prevalence rates, besides suggesting that schistosomiasis mansoni in the area is manifested as a light and somewhat harmless infection with little consequence for the population as a whole.

\section{N T R O D U C T I O N}

Schistosomiasis mansoni has long been considered a world problem deserving much care and attention from public health workers. Its wide geographic distribution, the high number of infected people and the possibility of its development into a severe form emphasize its importance as a public health problem. Many Authors throughout the world $2,4,5,6,18,20,22,26$, 27,30 have pointed out the need of epidemiologic studies regarding schistosomiasis mansoni in endemic areas, in order to better evaluate its natural history and the real impact the disease might have on populations.
The present study aims to evaluate schistosomiasis mansoni in a small Brazilian community through a population-based approach, emphasizing relevant clinical and epidemiologic aspects and their impact in the community.

\section{MATERIAL AND METHODS}

The community, Tuparecê, is located within the northeast part of Minas Gerais State, Central region of Brazil. It has long been considered an endemic area for schistosomiasis presenting hyperendemicity characteristics 4,16 . Tu-

(1) Sponsored by the CNPq (Conselho Nacional de Desenvolvimento Científico e Tecnológico), Brazil

(2) Assistant Professor - Department of Preventive and Social Medicine, Faculty of Medicine-Federal University of Minas Gerais

(3) Medical Trainee - Department of Preventive and Social Medicine, Faculty of Medicine, Federal University of Minas Gerais

(4) "René Rachou" Research Center - FIOCRUZ, 30.000 - Belo Horizonte - MG, Brazil 
GUIMARAES, M. D. C.; BARROS, H. L. de \& KATZ, N. - A clinical epidemiologic study in a schistosomiasis mansoni endemic area (Tuparecê, Minas Gerais). Rev. Inst. Med. trop. São Paulo 27:123-131, 1985.

parecê has 830 inhabitants and is located 800 $\mathrm{km}$ from the State capital, Belo Horizonte, where laboratory examinations were performed.

\section{Stool Examination}

The stool examination was performed using Kato as modified by KATZ et al. ${ }^{7}$ method. The S. mansoni eggs were counted and the mean of two thick smears considered the number of eggs per gram of feces. The intensity of S. mansoni infection was evaluated by the overall geometric mean number of eggs as well as by the proportion of low and high egg output $(<500$ and $>500$ eggs per gram of feces).

\section{Medical Interview and Physical Examination}

The patients were interviewed for symptoms, water contact and selected socio-economic characteristics such as family income, land property, presence of latrine, housing and time of residence in the area. The symptoms looked for were abdominal pain, diarrhea, blood-streaked-feces, hematemesis and enterorrhagia. Contact with natural water was evaluated as reasons of contact (bathing \& swimming, fishing, playing, dishwashing and laundering) as well as its frequency (once a day as daily and the remaining ones as less than daily). Past history included previous treatment to schistosomiasis, hematemesis, splenectomy, alcohol drinking habits, convulsions and jaundice.

Both, interview and physical examination, were carried out without previous knowledge of the stool examination results.

All patients, except children under two years of age, were examined for liver and spleen enlargement. Liver right lobe size was measured in centimeters from the right costal margin at the hemiclavicular line, liver left lobe size from the left costal margin. Livers were considered palpable when measuring 1 centimeter or more without respiratory manoeuvre and their consistencies were evaluated as normal, hardened and hard. Those patients positive to schistosomiasis at the stool examination were classified in four clinical forms according to PESSOA \& BARROS 27 as follows: intestinal form (palpable left and/or right liver lobes, spleen not palpable), hepatosplenic form (hardened or hard palpable liver and spleen) and hepatosplenic decompensated (the same hepatosplenic form characteristics with portal hypertension signs such as ascites, jaundice, prominent abdominal veins). For the purpose of clinical classification, children under 5 years of age were excluded from the study 29 .

\section{Statistical Analysis}

Selected statistics test used were: Student's t-test for the difference of means, Chi-square test for the difference of proportion, Odds Ratio based on 'Woolf's method 33 presenting $95 \%$ confidence limits for selected risk factors and Odds Ratio for multiple category table ${ }^{23}$. The significance level considered was 0.05 .

\section{RESULTS}

The census developed in the community presented 830 people eligible for the study $(50,2 \%$ males and $49.8 \%$ females), $777(93.6 \%)$ had their stools examined while in $696(83.9 \%)$ a physical examination was carried out. The overall index of infection to $\mathbf{S}$. mansoni was 43.2 and the geometric mean number of eggs was 85.9 .

No significant difference was found with regard to selected risk factors such as sex, race, infection with other helminth, past treatment, land property, housing and absence of latrine when comparing positives and negatives (Table I). Increased infection risk (95\% confidence limits) could be detected for the young age group (2-14 years old) regarding any occupation, time of residence in the area $(>10$ years) daily frequency and any reasons of water contact while for the age group (15 years old and over) no significant risk was found ('Table II).

There was a close correlation between water contact and the index of infection for both sexes, males and females, in all age groups (Fig. 1). The index of infection increased parallel to the number of water contact up to 10-14 age group, there was a fall for 20-24 years old and a somewhat stable figure thereafter.

The analysis of selected symptoms as well as the physical examination did not show a very significant morbidity due to schistosomiasis. There was neither hematemesis nor enterorrhagia in both negative and positive groups. $\mathbf{A b}$ dominal pain showed no statistically significant 
GUIMARÄES, M. D. C.; BARROS, H. L. de \& KATZ, N. - A clinical epidemiologic study in a schistosomiasis mansoni endemic area (Tuparecê, Minas Gerais). Rev. Inst. Med, trop. São Paulo 27:123-131, 1985.

\section{T A B L I I}

Percent distribution and mean value of selected characteristics according to Schistosomiasis mansoni positivity ${ }^{1}$, in Tuparecê, Minas Gerais, 1981

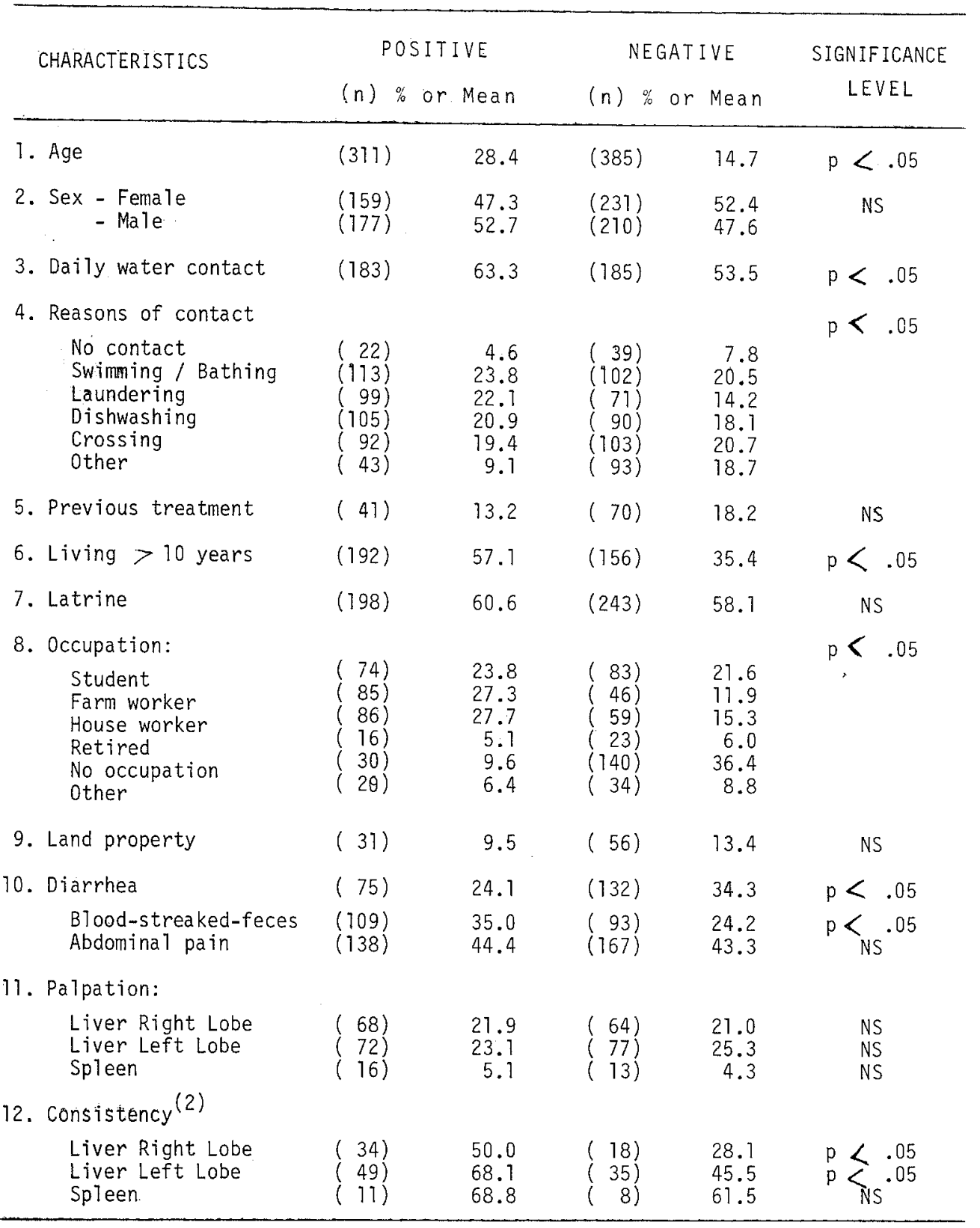

(1) - Presence or absence of Schistosoma mansoni eggs in the stools.

(2) - Shown the percentage in relation to item 11, when the consistency was hard and/or hardened.

difference, while diarrhea was more prevalent among negatives and blood-streaked-feces among positives (Table I). Palpation of liver and spleen showed no significant difference when comparing positives and negatives. With regard to consistency, those with schistosomia- 
GUIMARAES, M. D. C.; BARROS, H. L. de \& KATZ, N. - A clinical epidemiologic study in a schistosomiasis mansoni endemic area (Tuparecê, Minas Gerais). Rev. Inst. Med. trop. São Paulo 27:123-131, 1985.

T A B L E II

Schistosoma mansoni infection risks for selected characteristic according to age groups in Tuparecê Minas Gerais, 1981

\begin{tabular}{|c|c|c|}
\hline . CHARACTERISTICS & $\begin{array}{c}2-14^{7} \\
0 . R^{2} \\
\text { (Confidence Interval) }\end{array}$ & $\begin{array}{c}15^{+} \\
0 . R . \\
\text { (Confidence Interval) }\end{array}$ \\
\hline $\begin{array}{l}\text { 1. Frequency of water contact } \\
\text { (daily contact) }\end{array}$ & $\begin{array}{c}2.52 \\
(1.25-5.08)^{*}\end{array}$ & $(.49-1.78)^{.93} \mathrm{NS}^{3}$ \\
\hline \multicolumn{3}{|l|}{ 2. Occupation: } \\
\hline Student & $\begin{array}{c}4.96 \\
(2.85-8.65)\end{array}$ & $\begin{array}{c}2.60 \\
(.46-14.83)^{N S}\end{array}$ \\
\hline Farm worker & $\begin{array}{c}13.15 \\
(2.76-62.60)^{\star}\end{array}$ & $\begin{array}{c}1.38 \\
(.47-4.09)^{N S}\end{array}$ \\
\hline House worker & $\begin{array}{c}22.72 \\
(5.26-98.10)^{*}\end{array}$ & $\left(\begin{array}{c}1.03 \\
(.35-3.03)^{N S}\end{array}\right.$ \\
\hline Retired & - & $(.16-1.78)^{N S}$ \\
\hline $\begin{array}{l}\text { Other } \\
\text { 3. Reasons of contact: }\end{array}$ & - & $(.14-1.45)^{\mathrm{NS}}$ \\
\hline Swimming / Bathing & $\begin{array}{c}5.22 \\
(1.47-18.55)^{*}\end{array}$ & $\begin{array}{c}1.60 \\
(.75-3.42)^{N S}\end{array}$ \\
\hline Dishwashing & 6.83 & 1.25 \\
\hline Laundering & $\begin{array}{c}(1.88-24.74)^{*} \\
9.80\end{array}$ & $\left(\begin{array}{c}.60-2.63)^{\mathrm{NS}} \\
1.32\end{array}\right.$ \\
\hline Crossing & $\begin{array}{c}(2.28-42.06)^{\star} \\
4.33\end{array}$ & $\therefore\left(\begin{array}{c}.64-2.71)^{\mathrm{NS}} \\
1.03\end{array}\right.$ \\
\hline other & $\begin{array}{c}(1.18-15.90)^{\star} \\
1.14 \\
(.30-4.36)^{\mathrm{NS}}\end{array}$ & $\begin{array}{c}(.49-2.13)^{\mathrm{NS}} \\
2.19 \\
(.87-5.46)^{\mathrm{NS}}\end{array}$ \\
\hline $\begin{array}{r}\text { 4. Time of Residence } \\
(>10 \text { years })\end{array}$ & $\begin{array}{c}4.01 \\
(1.85-8.71)^{\star}\end{array}$ & $\begin{array}{c}1.15 \\
(.61-2.19)^{\mathrm{NS}}\end{array}$ \\
\hline
\end{tabular}

(1) Years old

(2) Odds Ratio

(3) Non-statistically significant interval

(*) Statistically significant interval $p<0.05$

sis presented more hard left and right lobes than those without schistosomiasis, while spleens showed no significant difference (Table I).
Mean age was significantly lower among those presenting high egg output, while most of the positive subjects (88.4\%) had low egg output. 
GUIMARAES, M. D. C.; BARROS, H. L. de \& KATZ, N. - A clinical epidemiologic study in a schistosomiasis mansoni endemic area (Tuparecê, Minas Gerais). Rev. Inst. Med. trop. São Paulo 27:123-131, 1985.

\section{DISCUSSION}

The need of studies which evaluate the consequences of schistosomiasis mansoni in a whole population has long been considered of outstanding importance, not only for a better understanding of the individual behaviour of the disease, but also for the development of an appropriate public health approach for its control. Two often used methods for this evaluation, namely, the number of infected people and the intensity of the infection in the community, have brought about a clear distinction between schistosomiasis-infection and schistosomiasis disease. Emphasis has been placed on the latter since most studies performed are clinical and/or hospital based, and some population-based surveys lack a negative control group, usually due to the high number of infected subjects. The present study tried to overcome these problems by developing a population-based approach as well as a control group for comparison with those infected people regarding selected risk factors and consequences of the S. mansoni infection.

Most variables measured in the present study showed no statistically significant difference when positives and negatives were compared. Several Authors have pointed out similar results regarding sex and/or race $1,2,4,18,22$. While DIAS $^{9}$ and FAROOQ \& MALLAH 10 found higher prevalence among males, although these differences were due mostly to social and religious practices. A fall in schistosomiasis prevalence shortly after treatment is usually found, but as time passes and the possibilities of exposure do not decrease high re-infection rates, specially among children are common 3,6,7,18,19.

In fact, in the present study no significant difference with respect to past treatment, when comparing positives with negatives, was found even though the time considered was up to ten years before interview.

Different patterns of exposure to water vary from place to place where schistosomiasis mansoni studies are carried out, because exposure depends upon socio-economic level and professional and leisure activities. JOBIN \& RUIZ-TIBEN 13 reported that most contacts were caused by play, bathing and laundering and that school children had the highest proportion of water contact among all groups. In Egypt, male children up to 10 years old accounted for 50 percent of the total activity in water, and water contact was mostly due to bathing and SWIMMING ${ }^{10}$. In St. Lucia, JORDAN 14 pointed out a close correlation between percentage of contact with natura. water and percentage of schistosomiasis cases by age and sex.

In the present study, similar results have been obtained with regard to contact with water and index of infection (Fig. 1). The same rise in the index of infection was followed by a rise in the percentage of water contact. The most common reasons of contact were bathing, swim ming, dishwashing and laundering. The age-prevalence curve presented in the study (Fig. 2) is in accord with most investigations to date 4,11, $14,22,25,26,28,30$. There is a steep rise from the first decade of life with a maximum peak in the second decade and a relatively constant prevalence thereafter. Age has actually been one of the most important factors in determining S. mansoni infection in the area as can be seen tinrough the estimated risks reported in this investigation (Table II). Water contact pat terns are determined by age, which is in accord with the above mentioned studies. The risk of becoming infected is greater for young people (less than 15 years old) than for adults, since the latter are, in most instances, already infected. PESSOA \& AMORIM 28 have already mentioned that "schistosomiasis is a disease of young people and that adult schistosomiasis is generally the result of infections acquired in youth".

Despite the fact that ecology has played an important role in determining schistosome infection patterns in this area, immunological mechanisms might have influenced this and other endemic areas with regard to the age pattern herein presented. More epidemiologic investigations must be carried out in order to evaluate the real significance of immunological factors in a general population instead of analysing only individual factors ${ }^{8}$. Most probably the decrease of prevalence in older ages is due to a combination of both immunity ecology.

Clinical severity of chronic schistosomiasis has often been evaluated by the stated symptomatology, spleen and liver size as well as their respective consistency. In the present study the only symptom found to be statistically significant different was blood-streaked-feces, but sin. 

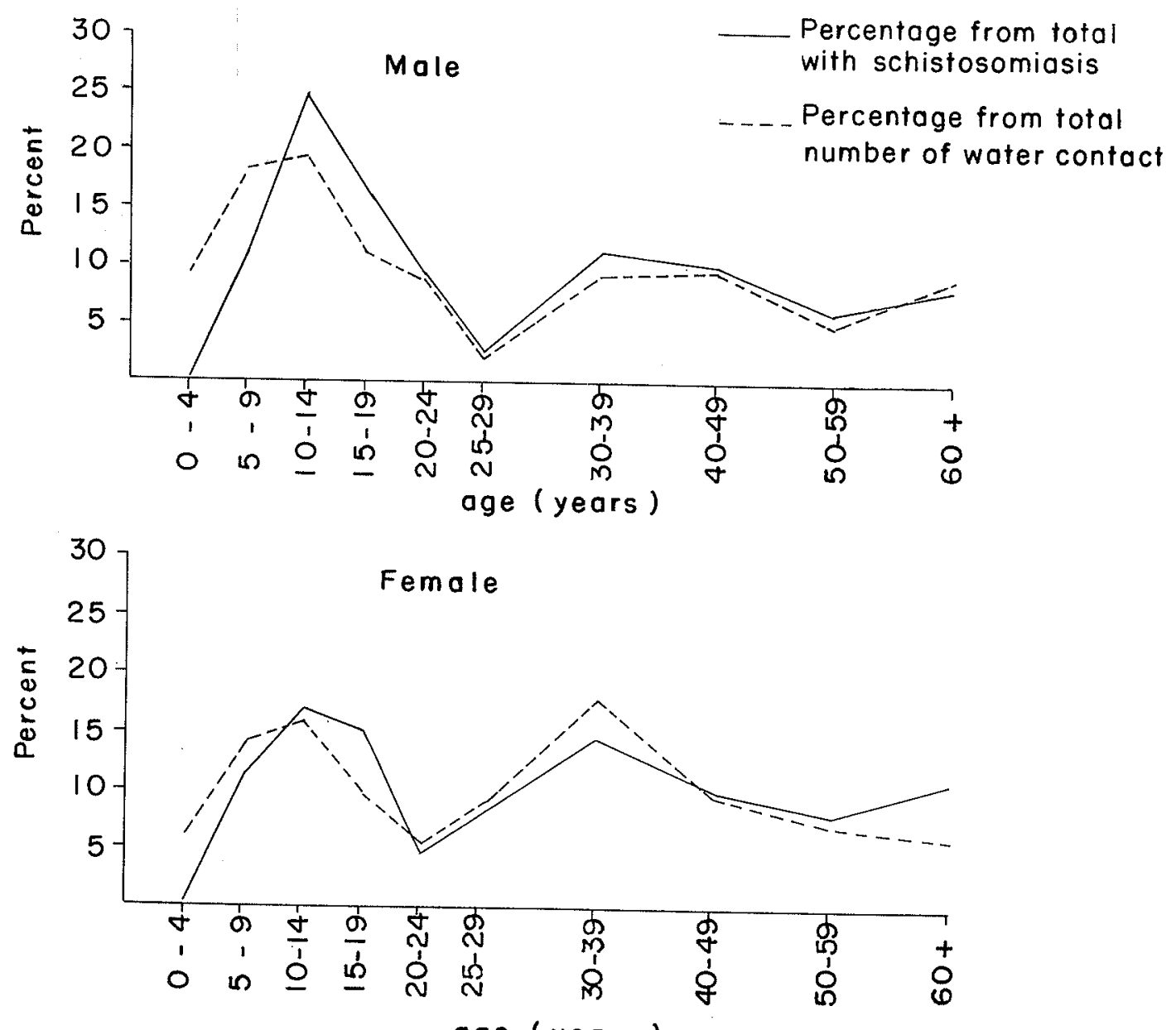

Fig. 1 - Correlation between stated water contact and $\mathbf{s}$. mansoni infection by Age and Sex, in Tuparecê, Brazil, in 1981.

ce other helminth and protozoa infections are common in the region, it can not be said that this symptom was actually due to schistosomiasis. Similar results were found by HIATT ${ }^{11}$ and OMER et al. ${ }^{25}$, while BARBOSA ${ }^{1}$ and COOK et al. ${ }^{5}$ found no difference in any of the symptomes analysed. With regard to spleen and liver size, some Authors 6,30 have found a significant difference in splenomegaly and/or hepatomegaly when comparing a heavy-moderate group with those uninfected while CLINE et al. ${ }^{5}$ pointed out that palpable liver occurred more frequently among those infected 20 years old or more. In the present study no significant difference was found regarding spleen and liver palpation when comparing either positives with negatives, or low egg-output with high egg- output. We have found that there is not a very clear clinical picture that could be attributed to schistosomiasis despite the evidence of some significant differences. This is in accord with many Authors who have shown that $\mathbf{S}$. mansoni infection in some endemic areas is usually assymptomatic with low morbidity levels 5,6, 21,23 .

Following the points mentioned above and taking into consideration the nature of the present study, that is, a clinical-epidemiologic and population-based survey, two conclusions shall be regarded as important: (1) Age, as presented in this investigation is considered an outstanding risk factor for acquiring S. mansoni infection (with young subjects being at a higher risk), and emphasis is placed on the importance 


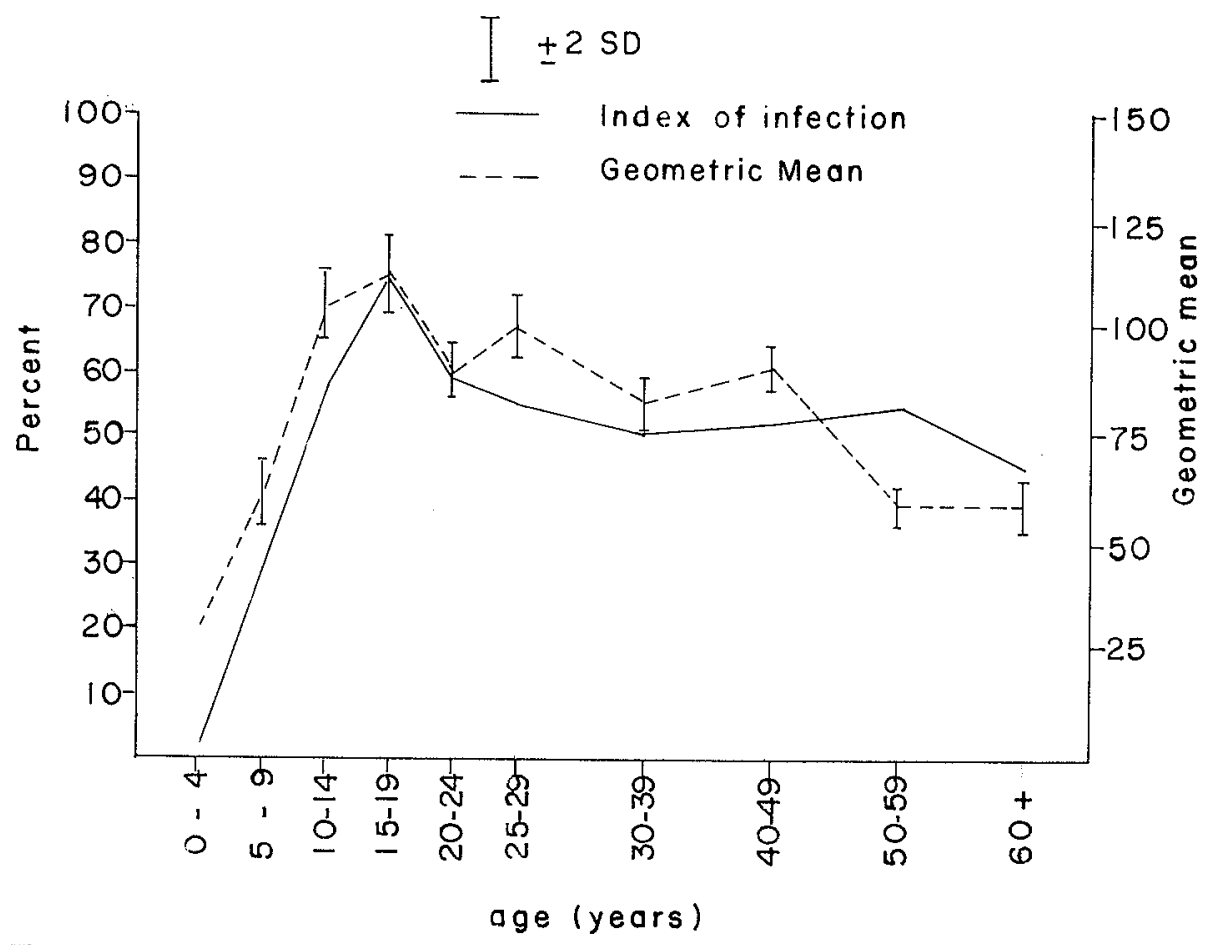

Fig. 2 - Percent Distribution of $\mathbf{S}$. mansoni infection and Geometric Mean number of eggs per gram of feces by Age, in Tuparecê, Brazil, in 1981.

of population habits, and water contact patterns as one plausible explanation for this finding; (2) Schistosomiasis mansoni, in this investigation, is manifested with low morbidity and has no or little consequence for the population as a whole, emphasizing the distinction between infection and disease and their consequence to the community. More epidemiologic studies are needed for a better understanding of schistosomiasis mansoni's natural history and its consequences at the individual as well as the population level.

\section{RESUMO}

Estudo clínico-epidemiológico em uma área endêmica de esquistossomose mansoni (Tuparecê, Minas Gerais)

Foi feito um estudo clínico-epidemiológico da esquistossomose mansoni na população de Tuparecê, Minas Gerais. Foi realizado a entrevista com relação a sintomas, contato com águas naturais, história pregressa, tendo sido ainda examinados o baço e fígado. Das 830 pessoas registradas no censo, 777 (93,6\%) tiveram as fezes examinadas (método Kato-Katz) e $696(83,9 \%)$ foram clinicamente avaliadas. $O$ indice de infecção foi de $43,2 \%$ não tendo sido encontradas diferenças significativas quanto ao sexo, cor e a maior parte das variáveis sócioeconômicas. Foram encontrados maiores riscos de se adquirir a infecção no grupo etário mais jovem (2-14 anos) com relação a ocupação, tempo de residência na área e freqüência de contatos com águas naturais. Fezes com estrias sangüineas foram mais frequientes entre os positivos, enquanto que diarréia o foi entre os negativos. A morbidade e a intensidade da infecção, medida pelo número de ovos de Schis. tosoma mansoni por grama de fezes, foram baixas. Foi encontrada uma estreita correlação entre os padróes de contato com águas naturais e a curva de prevalência por idade. O presente trabalho enfatiza a importância dos hábitos na determinação dos índices de infecção além de apontar que a esquistossomose mansoni, nesta área, se manifestou sem graves consequiêncais para a população como um todo. 
GUIMARAES, M. D. C.; BARROS, H. L, de \& KATZ, N. - A clinical epidemiologic study in a schistosomiasis mansoni endemic area (Tuparecê, Minas Gerais). Rev. Inst. Med. trop. São Paulo 27:123-131, 1985.

\section{ACKNOWLEDGEMENTS}

This study would not have been possible without the support of the laboratory staff from "René Rachou" Research Center - FIOCRUZ, Belo Horizonte. We are particularly indebted to Prof. Carlos Maurício de Figueiredo Antunes for his valuable suggestions in statistics and epidemiology. We are also grateful to Tamara, Zezé, Vanil, Aninha, Bel, Angelo and Sandra for their valuable help with field work.

\section{REFERENCES}

1. BAREOSA, F. S. - Morbidade da esquistossomose. Rev. Brasil. Malariol. \& Doenças Trop. (N.॰ especial): 3-159, 1966.

2. BARBOSA, F. S. - Cross-sectional studies on Schistosoma mansoni infection in Northeast Brazil. Ann. Trop. Med. and Paxasitol. 69: 207-216, 1975.

3. BINA, J. C. \& PRATA, A. - Hycanthone no tratamento da esquistossomose em uma área com baixo índice de transmissão da doença. Gazeta Méd. Bahia 70: $127-130,1970$

4. BRENER, Z. \& MOUR.ĀO, O. G. - Inquéritos clínicoepidemiológicos em focos endêmicos de esquistossomose mansoni em Minas Gerais. Rev. Brasil. Malariol. \& Doenças Trop. 8: 519-525, 1956.

5. CLINE, B. L.; RYMZO, W. T.; HIATT, R. A. KNIGHT, W. B. \& BERRIOS-DURAN, L. A. - Morbidity from Schistosoma mansoni in a Puerto Rican community: A population-based study. Amer. J. Trop. Med. \& Hyg. 26: 109-117, 1977 .

6. COOK, J. A.; BAKER, S. T. ; WARREN, K. S. \& JOURDAN, P. - A controlled study of morbidity of schistosomiasis mansoni in St. Lucia children, based on quantitative egg excretion. Amer. J. Trop. Med. \& Hyg. 23: 625-633, 1974.

7. COSTA, M. F. F. L.; KATZ, N. \& DIAS, J. C. P. Reinfecção de pacientes em áreas endêmicas de esquis. tossomose mansoni após tratamento específico. Rev. Inst. Med. trop. São Paulo 22: 97-105, 1980.

8. CROFTON, H. D. - A model of host-parasite relationships. Parasitology 63: 219-246, 1959.

9. DIAS, E. - Estudos preliminares sobre a esquistossomose mansoni no Município de Bambuí, Estado de Minas Gerais. Rev. Brasil. Malariol. 5: 211-215, 1953.

10. FAROOQ, M. \& MALLAH, M. B. - The behavioural patterns of social and religious water-contact activities in the Egypt-49 bilharziasis project area. Bull. World Health Org. 35: 377-387, 1966.

11. HIATT, R. A. - Morbidity from Schistosoma mansoni infections: An epidemiology study based on quantita- tive analysis of egg excretion in two highland Ethipian villages. Amer. J. Trop. Med. \& Hyg. 25: 808-817, 1976.

12. HUSTING, E. L. - Sociological patterns and their influence on the transmission of bilharziasis. Central African J. Med. 16: (suppl.) 5-10, 1970.

13. JOBIN, W. R. \& RUIZ-TIBEN, E. - Bilharziasis and patterns of human contact with water in Puerto Rico. Bol. As. Med. Puerto Rico 60: 279-284, 1968.

14. JORDAN, P. - Epidemiology and control of schistosomiasis. Brit. Med. Bull. 28: 55-59, 1972.

15. JORDAN, P.; CHRISTIE, J. D. \& UNRAU, G. O. Schistosomiasis transmission with particular reference to possible ecological and biological methods of con. trol. Acta Trop. 37: 95-135, 1980.

16. KATZ, N. \& BRENER, Z. - Evolução de 112 casos de esquistossomose mansoni observados após 10 anos de permanência em focos endêmicos de Minas Gerais. Rev. Inst. Med. trop. São Paulo 8: 139-142, 1965.

17. KATZ, N.; CHAVES, A. \& PELLEGRINO, J. - A simple device for quantitative stool thick-smear technique in schistosomiasis mansoni. Rev. Inst. Med. trop. São Paulo 14: 397-400, 1972.

18. KATZ, N.; ZICKER, F.; ROCHA, R. S. \& OLIVEIRA, V. B. - Reinfection of patients in schistosomiasis endemic areas after specific treatment. I - Influence of age and worm burden. Rev. Inst. Med: trop. São Paulo 20: 273-314, 1978.

19. KATZ, N. - Experiência com quimioterapia em grande escala no controle da esquistossomose no Brasil. Rev. Inst. Med. trop. São Paulo 22: 40-51, 1980.

20. KLOETZEL, $\mathbb{K}$. - Splenomegaly in schistosomiasis. Amer. J. Trop. Med. \& Hyg. 11: 472-476, 1962.

21. KLOFTZEL, K. - Alguns novos conceitos sobre a epidemiologia da esquistossomose. Hospital (Rio) 75: 333$335,1969$.

22. LEHMAN, J. S.; MOTT, K. E.; MORROW Jr., R. H.; MUNIZ, T. M. \& BOYER, M. H. - The intensity and effects of infection with Schistosoma mansoni in a rural community in Northeast Erazil. Amer. J. Trop. Med. \& Hyg. 25: 285-294, 1976.

23. LILIENFELD, A. M. \& LILIENFELD, D. E. - Foundation of Epidemiology. Second edition. New York, Oxford University Press, 1980

24. MEMORANDA - Immunology of Schistosomiasis. Bull. World Health Org. 51: 553-595, 1976.

25. OMER, A. H. S.; HAMILTON, P. J. S.; MARSHALL, T. F. de C. \& DRAPER, C. C. - Infection with Schistosoma mansoni in the Gezira area of the Sudan. J. Trop. Med. \& Hyg. 79: 151-157, 1976.

26. ONGOM, V. L. \& BRADLEY, D. J. - The epidemio logy and consequence of Schistosoma mansoni infection 
GUIMARAES, M. D. C.; BARROS, H. L. de \& KATZ, N. - A clinical epidemiologic study in a schistosomiasis mansoni endemic area (Tuparecê, Minas Gerais). Rev. Inst. Med. trop. São Panlo 27:123-131, 1985.

in the West Nile, Uganda. Trans. Royal Soc. Trop. Med. \& Hyg. 66: 835-851, 1972.

27. PESSOA, S. E. \& BARROS, P. R. - Notas sobre a epidemiologia da esquistossomose mansônica no estado de Sergipe. Rev. Méd. Cirúrg. São Paulo 13: 147-154, 1953.

28. PESSOA, S. B. \& AMORIM, J. P. - Contribuição para a história natural da esquistossomose mansônica no Nordeste Brasileiro e sugestões para sua profilaxia. Rev. Brasil. Malariol. \& Doenças Trop. 9: 5-8, 1957.

29. ROMEIRO, V. - Semítica do Fígado $\theta$ das vias biliares. In: Semiologia Médica. 11a. ed., V. 2. Rio de Janeiro, Guanabara Koogan, 1968.

30. STONGOK, T. K. A.; MAHMOUD, A. A. F.; OUMA, J. H.; WARREN, K. S.; MULLER, A. S. ; HANDA, A. K. \& HOUSER, F. B. - Morbidity in schistosomiasis mansoni in relation to intensity of infection: study of a community in Machakos, Kenya. Amer. J. Trop. Med. \& Hyg. 25: 273-284, 1976.

31. TAYO, M. A.; PUGH, R. N. H. \& BRADLEY, A. K. - Malumfashi endemic disease research project. XI. Water-contact activities in the schistosomiasis study area. Ann. Trop. Med. \& Parasitol. 74: 347-354, 1980.

32. WARREN, K. S. - Regulation of the prevalence and intensity of schistosomiasis in Man: Immunology or Ecology? J. Infect. Dis. 127: 595-609, 1973.

33. WOOLF, B. - On estimating the relation between blood group and disease. Ann. Human Genetic 19: $251-253,1954 / 5$.

Recebido para publicação em 20/10/1983. 